\title{
P-345胎仔期および新生仔期のDES睅露による造 精機能への影響
}

\begin{abstract}
名古屋市立大学 ${ }^{1)}$

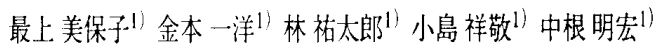

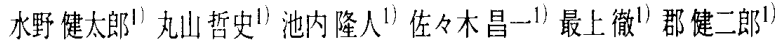

【日的】胎仔期㧍よび新生仔期に曝露したDiethylstilbestrol(DES)が思 春期以降の造精機能にどのような影響をあたえるか実験的に検討 した。【方法】（1）妊張後期のSD雃ラットにDESを $100 \mu \mathrm{g} / \mathrm{kg}$ 腹腔 内投与し出生した雄ラット（A群）拈よび（2）新生仔期（出生 後2-12日）にDESを10 $\mu \mathrm{g}$ 投与した雄ラット（B群）について以下 の検討を行った。DES非投与ラットをコントロール（C 群）とし た。1)精巣重量の検討 2)精巣の組織障害及びTUNEL法によるア ポトーシスの発現 3)七ルトリ細胞におけるアンドロゲンレセプ ターの発現【結果】1)精巣重量は 4 週齢でA群 $0.36 \mathrm{~g} \mathrm{~B}$ B群 $0.32 \mathrm{~g} \mathrm{C}$ 群 $0.52 \mathrm{~g} \mathrm{l} 10$ 週路0.54 g、0.45 g, $1.64 \mathrm{~g}$ であった。2)精巣組織は、A群 B群ともに精子形成細胞の脱落や間質の脱落が認められた。さら に精子形成細胞にお㧍るアポトーシス検出細胞は週齢とともに優 位に増加していた。3)七ルトリ細胞におけるアンドロゲンレセプ ターの発現はA群B群に扔いて優位に低下していた。考察】胎仔 期掞よび新生仔期のDESの曝露は、思春期以降の造精機能に影響 をきたすことが示唆された。またこのことはDESのセルトリ細胞 への直接作用を介している叮能性が示唆された。
\end{abstract}

造精機能 DES 思春期
P-346 低温ショック蛋白マウスRbm3の単離、お よび精巣における発現の検討

\section{関西医科大学 泌尿器科 ${ }^{1}$ 京都大学 分子病診療学 ${ }^{2}$}

檀野祥三1）六車光英1）松田公志1）藤田 潤2)

【背景・目的】我々はこれまでに低温ショック蛋白（Cirp）が精雀 に於いて精母細胞に強く発現し、実験的停留精巣拉よび精索静脈

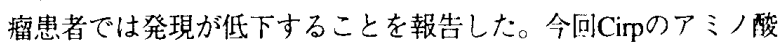
配列と65\%と高い相同性を持つマウスRbm3を単離し、低温ショッ クによる発現への影響、マウス精巣に打ける発現部位、実験的停 留精巣の発現への影響について検討した。【方法】ESTを用いてヒ トRBM3のマウスホモログであるRbm3のcDNA配列を決定した。 低温ショックを加えたマウス培養細胞からRNAを抽出し、ノーザ ンブロット法、ウエスタンブロット法を用いて発現量を検討した。 マウス精巣における発現はノーザンブロット法、免疫染色法を用 いて検討した。【結果】 Rbm3はCirpと同様に $32^{\circ} \mathrm{C}$ 低温ショック にて発現が誘導された。マウス精巣ではセルトリ細胞に特異的に 発現していた。また胎仔精巣には発現を認めず、出生直後から発 現を認めた。実験的停留精巣では発現の低下が認められた。【総 括】セルトリ細胞は精子形成に重要と考えられている様々な蛋白 を分泌している。 Rbm3は七ルトリ細胞に特異的に発現して抢り、 精子形成が障害されるような温度環境では発現が低下することか らセルトリ細胞の遺伝子発現の温度感受性に関与しているのかも しれない。

低温ショック蛋白 セルトリ細胞 停留精策

\section{P-347精子細胞特異的に発現するPEBP $2 \alpha$ $\mathrm{A}(\mathrm{cbfa} 1)$ 遗伝子産物の解析}

\author{
東北大学 医学部 泌尿器科1) 国立仙台病院 ${ }^{2)}$ \\ 加龄医学研究所免疫遗伝子制御 ${ }^{3)}$

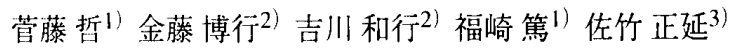 \\ 折笠 精...1)
}

PEBP2遺伝子はへテロダイマーからなる転写因子である。PEBP2 ファミリーのなかでPEBP2 $\alpha \mathrm{A}$ （cbfa）の発現は骨、胸腺、精巣 と組織特買性が高い。骨に执いては骨芽細胞に強い発現を認め、 PEBP $\alpha \mathrm{A}$ (cbfal) の)ックアウトマウスでは骨の発生は阻害さ れ膜性骨化及び軟骨内骨化の完全欠損を認める。我々は第85回泌

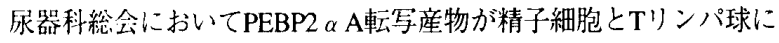
扔いて細胞特異的に分別して発現制御されることを報告した。す なわちPEBP2 $\alpha \mathrm{A}$ (cbfa1) は精巣のなかでも半数体である精子細 胞に特罢的に強く発現しており、cDNA及びゲノムDNAの構造解 析により、精樂ではTリンパ球とは異なるプロモーターによりそ の発現が制御されから上流エクソンとポリA付加部位の異なった 転宁産物が産生されることを明らかとした。現在PEBP $2 \alpha \mathrm{A}$ (cbfal) は異なるプロモーターまたはスプライシングの違いによ る3つの異なる転写産物の存在が報告されている。我々はこの度 精子細胞で発現しているPEBP $2 \alpha$ A転写産物の全長の構造を明ら かとし、転写因子として必須であるRUNTドメイン及び転写活性 化ドメインを欠如する新しい読みとり枠を上流に同定した。この 遺伝子産物はウエスタンブロットにより精巣中に $12 \mathrm{kDa}$ の蛋白と して検出される。精子細胞に特異的に発現するこの新規の蛋白の 発現を解析した結果を報告する。

PEBP2 $\alpha$ A cbfa1 精子細胞

\section{P-348 ヒト精巣に発現する精子形成関連遭伝子の 検討 - Preliminary study -}

\begin{abstract}
徳島大学 医学部 泌尿器科学教室 ${ }^{1}$ ) 徳島大学 医学部 公衆衛生学教室 ${ }^{2}$ ) 奈路田拓史 ${ }^{1 /}$ 黑木 陽子2) 新家利-2) 金山博臣1) 中䖯豊2) 香川征

【目的】ヒト精巣で発現する精子形成関連遺伝子の问定を試みた。 【対象・方法】ヒ卜精巣組織は、当院不妊外来を受診し、精巣生: 検を施行した症例から同意を得て採取した。組織学的に、1) Germ cell aplasia (Sertoli cell only synd.)、2) Maturation arrest、3) Normal spermatogenesis（Obstructive azoospermia）と診断されたサン プルから、それぞれtotal RNA を抽出し、 differential display (DD) による解析を行った。【結果】各サンプル間で、異なるシグナル 強度を示すバンドが、複数闰定された。遺伝子発現量が異なると 考えられるバンドを回収し、ベクターヘサブクローン後、塩基配 列を決定した。データベース上での検索で、相同性の高いEST (expressed sequence taq) が複数ピックアップされた（相同性 $89 \%$ 以 上）。また、決定した塩基配列をもとに作成したprimer でRT-PCR を行うと、各サンプル間で、PCR products 量の多少は、DD の結果 と一致した。【結語】現在えられているサブクローンは、ほとん どが150-300bp 程度で情報量にそしく、から反復配列が挿入されて いるものも多く、解析を困難にしている。現在、RACE（rapid amplification of cDNA ends）-PCRにてクローニング中である。
\end{abstract}

DD EST RACE-PCR 